\title{
The environmental and economic aspects of a biogas power plant
}

\author{
Gy. Szabó ${ }^{1}$, I. Fazekas ${ }^{1}$, K. Kisari ${ }^{2}$, T. Buday ${ }^{3}$, G. Szabó ${ }^{4}$, \\ Sz. Szabó ${ }^{4}$, M. Paládi ${ }^{1} \&$ A. Kerényi ${ }^{1}$ \\ ${ }^{I}$ Department of Landscape Protection and Environmental Geography, \\ University of Debrecen, Hungary \\ ${ }^{2}$ Agricultural Ltd. of Tiszaszentimre, Hungary \\ ${ }^{3}$ Department of Mineralogy and Geology, \\ University of Debrecen, Hungary \\ ${ }^{4}$ Department of Physical Geography and Geoinformatics, \\ University of Debrecen, Hungary
}

\begin{abstract}
In the present study we examined the carbon footprint of a biogas power plant in eastern Hungary, and the economic aspects of its operation. About $65 \%$ of the raw materials are transported from within a $12 \mathrm{~km}$ radius of the surrounding area; however, the remaining 35\% arrives from distances greater than $90 \mathrm{~km}$. In $2013-$ taking into consideration the complete life cycle of the power plant - the GHG (greenhouse gases) emission linked to each operational phase was 208,173 $\mathrm{kg} \mathrm{CO}_{2}$ equivalent, which is only $6.3 \%$ of the emission accompanying the production of the same quantity of energy in the Hungarian energy structure; therefore, from an environmental perspective, the energetic utilization of biogas is quite favorable. It became clear during an investigation into the economic aspects of the power plant's operation that in the current conditions its operation is on the margins of sustainability. The acquisition of raw materials must be rethought and rationalized. This can be achieved by 1) the replacement of the relatively expensive selfproduced feedstock by easily fermentable (bio) waste materials, and 2) the radical reduction of transportation distances. Moreover, it is imperative to find possible ways to utilize the surplus thermal energy and the sale of the fermented manure (biomanure) produced.
\end{abstract}

Keywords: biogas power plant, carbon footprint, GHG emission, cost-benefit analysis. 


\section{Introduction}

According to the 2014 report of the WBA (World Bioenergy Association) [1], between 2000 and 2011 the world's primary energy consumption increased by $30 \%$, and reached $552 \mathrm{EJ}$ by 2011 . For almost four decades the literature regarding energetics has stated that renewable energy sources constitute the basis of tomorrow's energy management.

Despite this claim, the actual utilization of renewable energy sources only showed an average $(32 \%)$ increase in the first decade of the $21^{\text {st }}$ century, thus representing a ratio of 13.25 within the world's primary energy consumption, $77 \%$ of which consists of biomass utilization [1]. In 2011, a total of $89 \%$ of the $54.9 \mathrm{EJ}$ energy produced worldwide from biomass was heat energy originating from biomass burning. The heat energy produced also played a crucial role in the energetic utilization of waste materials and biogases, but about $25-30 \%$ of these energy sources were linked to electric power production as well. Liquid biofuels mainly served the energy requirements of traffic and transportation.

The world's biogas production showed an exceptionally rapid increase in the first decade of the new millennium. The $292 \mathrm{PJ}$ global value in 2000 increased almost fourfold to exceed an annual value of $1.1 \mathrm{EJ}$ in 2011 [1].

In $2011,90 \%$ of the world's total biogas production and utilization was attributed to the European Union, China and the USA (Figure 1). In 2011, the European Union produced 428 PJ energy from biogas, so production increased 4.6 times in only 10 years. Having said this, it exploited only $15 \%$ of the theoretical biogas potential [2].

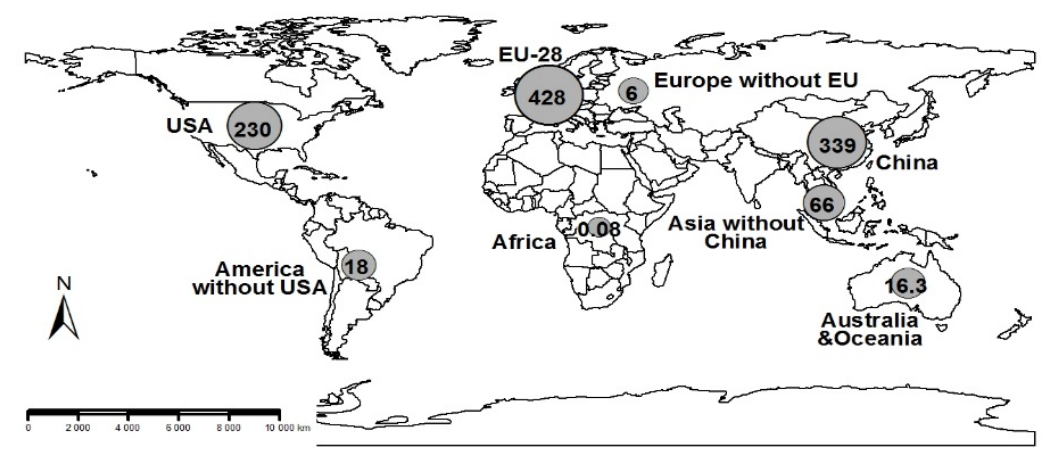

Figure 1: Biogas production in world regions (PJ) [2].

In the last decade, China and Asia (without China) have increased their energetically utilized biogas production sevenfold, although they have utilized only $3 \%$ of their theoretical potential. The third biggest global player in biogas production is the USA; with its $230 \mathrm{PJ}$ annual production it still makes up $20 \%$ of the sector, but compared to the other two world economic centers, with its slower growth it is gradually losing importance. In Latin America and Australia, the 
biogas sector has doubled in the latest decade, whereas in Africa, no real efforts have been made to exploit even a tiny fraction of the available potential [2].

In 2012, the approximately 13,800 biogas power plants in the EU represented a joint capacity of $7400 \mathrm{MW}_{\mathrm{e}}$ [3]. Two-thirds, one quarter and almost one-tenth of its biogas production originated from agricultural biogas factories, waste disposal sites and sewage treatment plants, respectively.

In Hungary, the first biogas factory to utilize agricultural waste energetically was built in 2003, in Nyírbátor. In October 2007, the first EU application was announced, which offered a non-refundable subsidy of up to $50 \%$ (to a maximum of 3 million Euros) of the total investment costs of building biogas power plants. This gave a spectacular boost to the national biogas sector between 2009 and 2012 (Figure 2).

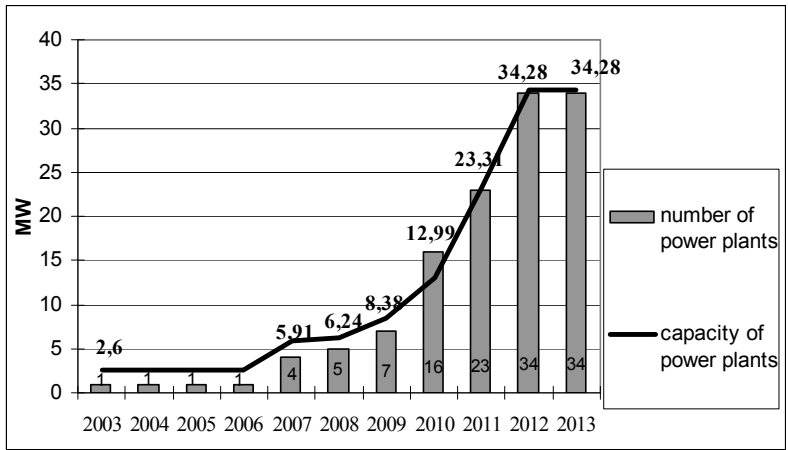

Figure 2: The number and capacity of biogas power plants using agricultural waste in Hungary.

Because after the spring of 2009 no further applications for building biogas power plants were announced, this rapid progress halted in 2013. By 2013, the number of Hungarian agricultural biogas power plants had reached 34, and their output performance exceeded 34.2 $\mathrm{MW}_{\mathrm{e}}$, thus providing about three-quarters of the total national biogas power plant capacity. The main raw materials (and at the same time, settling factors) for biogas power plants which use agricultural waste are cattle and pig liquid manure, so these were mainly built close to large scale livestock farms, such as the one at Tiszaszentimre that we chose as the subject of a detailed analysis in our study (Figure 3).

Achieving economic operation of the power plants is an important objective for management. In the literature, the majority of cost-benefit analyses related to biogas production are based on general presumptions, and not on the actual costs and incomes of a specific working plant [4-7]. Therefore, one of the main aims of our study was to investigate the actual costs and incomes of a particular power plant, and - based on the results - to draw conclusions about the sustainability of this type of biogas facilities.

In addition to the economic operation of biogas power plants, the environmental aspects must also be taken into consideration. Several authors have 
proved that the energetical use of biogas - compared to traditional energy production methods - involves a significantly lesser burden on the environment [8-11]. To verify this point, in our study we investigated the carbon footprint of the chosen biogas power plant, and - based on the results - we quantified the environmental advantages of biogas production.

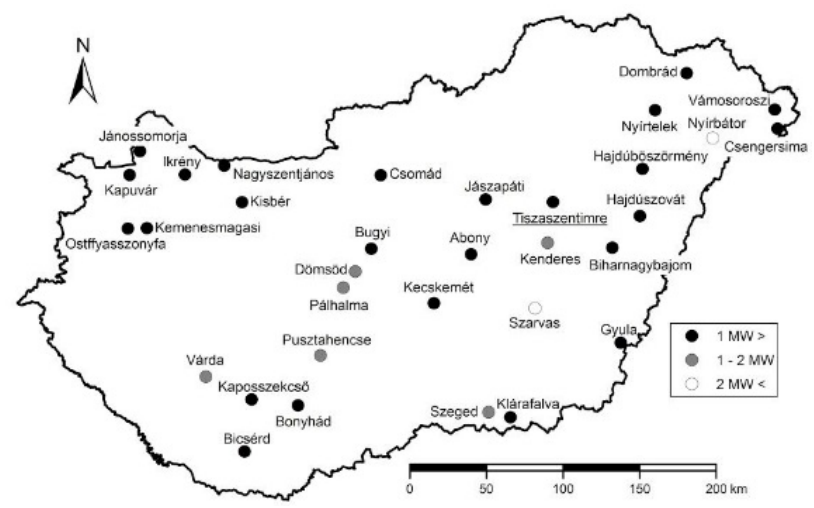

Figure 3: Agricultural biogas power plants in Hungary in 2014.

\section{Materials and methods}

\subsection{Calculation of the power plant's carbon footprint}

In our study - via the example of a Hungarian biogas power plant with an output of $0.637 \mathrm{MW}_{\mathrm{e}}$ - we demonstrate the changes in the carbon footprint and the operational costs in 2013, with reference to the complete life cycle of biogas production. The electrical capacity of the biogas power plant operated by Agricultural Ltd. of Tiszaszentimre is $637 \mathrm{~kW}$, its efficiency is $40.1 \%$, and its heat output is $682 \mathrm{~kW}$, with a $39.7 \%$ efficiency.

When calculating the carbon footprint, the emission values related to fuel consumption were based on the values given in the "Conversion factors", released by the Carbon Trust [12], in 2013. The calculation of the $\mathrm{CO}_{2}$ emission related to electric power utilization was based on a value of $0.370 \mathrm{~kg} \mathrm{CO} 2 \mathrm{e} / 1 \mathrm{kWh}$, established by the Hungarian energy structure [13]. Regarding raw materials, the $\mathrm{N}_{2} \mathrm{O}$ emission due to the use of artificial fertilizers was taken into consideration $[14,15]$, and for raw materials which arrived at the power plant as byproducts or as the waste of any production processes other than providing energy for the factory, only the $\mathrm{CO}_{2}$ emission - directly linked to the transportation to the plant - was considered.

The energy requirements of the units serving the power plant - which are provided by the national power network - were also taken into consideration. On the other hand, the energy needed for the operation of the power plant is provided by the electrical and thermal energy produced by the power plant itself. This energy is obtained by burning the $\mathrm{CH}_{4}$ produced in the digesters, while $\mathrm{CO}_{2}$ is 
released. However, its quantity cannot be more than that of the $\mathrm{CO}_{2}$ bound from the atmosphere during the organic material production; therefore, we omitted it from our calculations. In the case of the separated liquid and solid manure which leaves the power plant, we only calculated the GHG emission related to pumping them out, because solid manure (unless specific permission is granted) is not transferred to the arable land, but is completely recycled in the digesters, whereas the separated liquid manure is collected in the same storage unit where it would otherwise arrive from the livestock farms, so in reality it is linked to the farm's life cycle. Furthermore, we also considered the amount of energy used for business trips to ensure smooth operations and provide regular maintenance. Then, for each operational phase we determined the GHG emission values, which were converted to $\mathrm{CO}_{2}$ equivalents $\left(\mathrm{CO}_{2} \mathrm{e}\right)$, according to the Global Warming Potential (GWP) given in PAS 2050: 2011 [16], calculated for a 100-year period.

\subsection{Calculation of the power plant's operational costs}

The data regarding the operational costs in 2013 was provided by the power plant's management. Both the incomes and expenses are given in gross prices, in Euros, with the actual rate of exchange ( 1 EUR $=310$ HUF) valid at the time of writing this paper.

For the feedstock produced by the company that runs the power plant the production prices were taken into consideration, whereas for the raw materials originating from external business partners we used the current market prices. In the list of expenses we included the price of the electric power bought for the power plant's operation, the costs of maintenance in 2013, and also the calculated price of replacement items (canopy, mixer, Fliegel pulley, pumps, etc.), based on their estimated life span. In addition, we included in our calculation the employees' wages and the costs of any management business trips.

\section{Results and discussion}

\subsection{The results of the carbon footprint calculation of the biogas power plant}

The carbon footprint related to the feedstock production has two components: the $\mathrm{CO}_{2}$ emission of the machines used for the cultivation of the plants grown for utilization in the power plant, and the typical surplus $\mathrm{N}_{2} \mathrm{O}$ release at areas treated with artificial fertilizers. The machine usage had different rates for each type of plant. In the case of medick, hay and energy grass, machines were only used for the harvest, while for vetch and sweet sorghum several soil preparation and cultivation operations were also performed; in addition, for both plants a $27 \%$ nitrogen fertilizer called "pétisó" was spread, with 100 and $200 \mathrm{~kg} \mathrm{ha}^{-1}$ for vetch and sweet sorghum, respectively. The total fuel consumption of the arable farm machines (combine harvesters, etc.) was 22.6 thousand liters of fuel oil, which allowing for a $2.6008 \mathrm{~kg} \mathrm{CO}_{2}$ equivalent per liter - resulted in a total of 58.8 tons of $\mathrm{CO}_{2}$ emission in one year (Table 1). 
Table 1: The GHG emission in 2013, linked to the production of the feedstock grown for the power plant of Tiszaszentimre.

\begin{tabular}{|c|c|c|c|c|c|}
\hline Crop grown & $\begin{array}{c}\text { Cultivation } \\
\text { area (ha) }\end{array}$ & $\begin{array}{c}\text { Quantity } \\
\text { produced }(\mathrm{kg})\end{array}$ & $\begin{array}{c}\text { Fuel used by } \\
\text { machines } \\
(1 \text { diesel oil) }\end{array}$ & $\begin{array}{c}\text { The GHG } \\
\text { emission of } \\
\text { fuels }\left(\mathrm{kg} \mathrm{CO}_{2} \mathrm{e}\right)\end{array}$ & $\begin{array}{c}\text { GHG release } \\
\text { resulting from the } \\
\text { use of artificial } \\
\text { fertilizers } \\
\left(\mathrm{kg} \mathrm{CO}_{2} \mathrm{e}\right)\end{array}$ \\
\hline Sorghum & 125 & $2,517,450$ & 10,082 & 26,221 & 22,238 \\
\hline Vetch & 133 & $1,105,350$ & 6,126 & 15,931 & 23,661 \\
\hline Medick & 91 & $1,025,230$ & 5,466 & 14,217 & - \\
\hline Hay & 45 & 71,960 & 184 & 480 & - \\
\hline $\begin{array}{c}\text { "Szarvasi-1" } \\
\text { energy grass }\end{array}$ & 10 & $\mathbf{6 8 , 1 1 0}$ & $\mathbf{7 5 6}$ & 1,966 & - \\
\hline Total & $\mathbf{4 0 4}$ & $\mathbf{4 , 7 8 8 , 1 0 0}$ & $\mathbf{2 2 , 6 1 4}$ & $\mathbf{5 8 , 8 1 4}$ & $\mathbf{4 5 , 8 9 8}$ \\
\hline
\end{tabular}

In the case of vetch and sweet sorghum, the use of artificial fertilizers resulted in further GHG releases. The combined total of almost 46 tons of $\mathrm{CO}_{2}$ equivalent emission is quite significant; the reason for this is the GWP index of $\mathrm{N}_{2} \mathrm{O}$ (298), for a 100-year period. The received value of surplus $\mathrm{N}_{2} \mathrm{O}$ emission accords well with the calculated values based on the method given in the GHG Inventory [14], according to which, out of $1 \mathrm{~kg} \mathrm{~N}$ found in the artificial manure an average of 0.01 $\mathrm{kg} \mathrm{N} \mathrm{N}_{2} \mathrm{O}-\mathrm{N}$ may be released. In our case, this equals $48,412 \mathrm{~kg}$, expressed in $\mathrm{CO}_{2}$ equivalent. As a result, the total $\mathrm{GHG}$ emission during the raw material production comes close to a value of 105 tons/year $\mathrm{CO}_{2} \mathrm{e}$.

The materials utilized in the power plant reach the digesters in different ways. When calculating the carbon footprint related to transportation, we considered the quantities transported, the transportation method, the types of motor vehicles used and their fuel consumption, and the transport distances. In 2013, a total of $12,920 \mathrm{~m}^{3}$ of liquid pig manure arrived at the power plant, pumped in via a pipeline. The total electric power usage of the pump was $23,400 \mathrm{kWh}$, which is the equivalent of $8,190 \mathrm{~kg} \mathrm{CO}_{2} \mathrm{e}$ GHG emissions. From a nearby farm about 2,202 tons of farmyard cattle and pig manure was transported into the power plant; its calculated GHG emission was 2,086 $\mathrm{kg} \mathrm{CO}_{2} \mathrm{e}$ (Table 2). The various plants which were transported from the company's own arable land within a $12 \mathrm{~km}$ radius around the power plant weighed 4,788.1 tons, and the motor vehicles responsible for the transportation consumed 2,135 1 of fuel oil, which resulted in $5,553 \mathrm{~kg}$ of $\mathrm{CO}_{2} \mathrm{e}$ release (Table 2). Transport from greater distances significantly increased the carbon footprint. In 2013, biodiesel waste arrived from the Biodiesel Factory of Halmajugra and Nyíregyháza, and maize silage from Debrecen and Abádszalók.

All things considered, the 43.2 ton/year $\mathrm{CO}_{2} \mathrm{e}$ emission caused by motor vehicle transportation, and the GHG release of liquid manure transported into the power plant meant a total 51.4 ton $\mathrm{CO}_{2}$ e yearly emission as a result of material transfer.

The energy requirements of pouring/pumping the transported raw materials into in the digesters, mixing them there, transferring them between the main and the follow-up digesters, and cooling the gas engine are covered by the electrical and thermal energy generated by the power plant itself, whereas the energy for heating the fermenters is provided by the gas engine's waste heat. Therefore, the quantity of $\mathrm{CO}_{2}$ produced related to the above processes was omitted from 
the calculation of the factory's carbon footprint. The other element of the operational emission is the electric current consumption of the units serving the power plant, which is provided by the national power network. In 2013, this amounted to $117,685 \mathrm{kWh}$, which - based on the $0.37 \mathrm{~kg} \mathrm{CO}_{2} \mathrm{e} / 1 \mathrm{kWh}$ value, calculated according to the Hungarian energy structure - is equivalent to 43,543 $\mathrm{kg} \mathrm{CO} 2$.

Table 2: The GHG emission related to the transportation of feedstock by motor vehicles in 2013 .

\begin{tabular}{|l|c|c|c|c|c|}
\hline Type of feedstock & $\begin{array}{c}\text { Average } \\
\text { transportation } \\
\text { distance }(\mathrm{km})\end{array}$ & $\begin{array}{c}\text { Transported } \\
\text { quantity }(\mathrm{t})\end{array}$ & $\begin{array}{c}\text { Total distance } \\
\text { covered }(\mathrm{km})\end{array}$ & $\begin{array}{c}\text { Total fuel } \\
\text { consumption } \\
(1)\end{array}$ & $\begin{array}{c}\mathrm{kg} \\
\mathrm{CO}_{2} \mathrm{e}\end{array}$ \\
\hline Sweet sorghum & 5.5 & 2517 & 2585 & 689 & 1793 \\
\hline Vetch & 7.5 & 1105 & 2115 & 574 & 1492 \\
\hline Medick & 12.0 & 1025 & 3096 & 798 & 2075 \\
\hline Hay & 3.0 & 72 & 114 & 28 & 73 \\
\hline Energy grass & 8.0 & 68 & 176 & 46 & 120 \\
\hline Organic manure & 6.5 & 2202 & 3328 & 802 & 2086 \\
\hline Maize silage & 76.0 & 2212 & 12894 & 3868 & 10060 \\
\hline Biodiesel waste & 114.6 & 2381 & 24532 & 9813 & 25521 \\
\hline Total: & & $\mathbf{1 1 5 8 4}$ & $\mathbf{4 8 ~ 8 4 0}$ & $\mathbf{1 6 6 1 8}$ & $\mathbf{4 3 2 2 1}$ \\
\hline
\end{tabular}

The least significant part of the operational carbon footprint is the fuel consumption related to business trips and maintenance services. Their summarized yearly emission value equaled 7,946 $\mathrm{kg} \mathrm{CO}_{2} \mathrm{e}$.

Since the 1955 tons of solid biomanure produced by the power plant in 2013 was fully recycled into the digesters, we did not calculate their GHG emissions. The same is also true for the liquid-phase manure produced, because this should be considered when calculating the pig-farm's carbon footprint. Thus, of the power plant's waste materials only the waste oil from the motor of the biogas engine generator was taken into account. In 2013, a total of 3,135 1 of waste motor oil was transported from the plant a distance of $257 \mathrm{~km}$, where it was recycled; therefore in this case we need to calculate only the GHG release during transportation, which was the equivalent of $561 \mathrm{~kg} \mathrm{CO}_{2} \mathrm{e}$.

All in all, considering the complete life cycle of the power plant, in 2013 the GHG emission relating to all operational phases totalled $208,173 \mathrm{~kg} \mathrm{CO}$ equivalent (Figure 4).

In 2013, the power plant produced 4,347.21 MWh of electric power and 4,607.89 $\mathrm{MWh}$ of thermal energy. Had this been produced by the regular Hungarian energy structure, we should calculate a total 3,313,387 $\mathrm{kg} \mathrm{CO}_{2} \mathrm{e}$ emissions, i.e. almost 16 times more. The emissions related to the production of feedstock for the power plant constitute the dominant part of the carbon footprint. Here, in addition to the relatively high energy requirement of the agricultural machinery, the increase in the $\mathrm{N}_{2} \mathrm{O}$ release (linked to artificial fertilizers) also played an important part. The carbon footprint of the transportation of feedstock into the power plant is also high, due to the fact that (in 2013) about 35\% of the transported raw materials arrived from distances over $90 \mathrm{~km}$, which accounted for 
$81 \%$ of the total GHG emissions produced during transportation. The carbon footprint of the power plant could be primarily reduced by the optimization of the transport distances, and (in the case of the feedstock produced) by minimizing the use of artificial fertilizers.

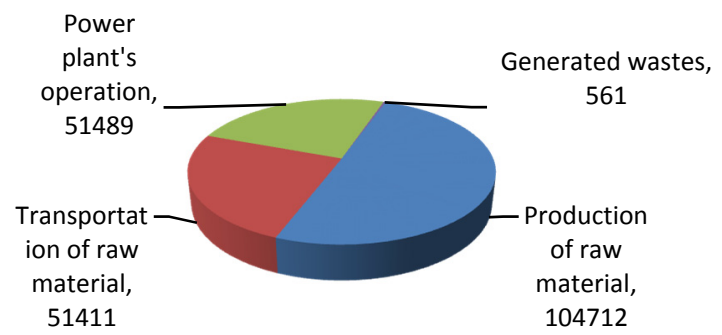

Figure 4: The GHG emission in the complete life cycle of biogas production, in 2013 (in $\mathrm{kg} \mathrm{CO}_{2} \mathrm{e}$ ).

\subsection{Cost-benefit analysis}

The total operational cost of the power plant was 3,459,347 EUR, 50\%, 31\% and $19 \%$ of which was funded by non-refundable EU grants, long-term (20-year) bank loans, and the company's own investments, respectively.

In the course of its operation in 2013, the power plant produced a total $2,095,888 \mathrm{~m}^{3}$ biogas, with an average $\mathrm{CH}_{4}$ content of $60 \%$. From the biogas produced it generated a total 4,347.2 MWh electric power, of which 3,753.5 MWh was sold, providing an income of 507,533 EUR. Out of the 4,607.9 MWh thermal energy produced by burning the biogas, 1,520.6 MWh was used to heat up the digesters, so this generated no direct income; on the other hand, the heating of the neighboring pig-farm was also covered by this energy, which meant a yearly 20,507 EUR saving ("income"). Since the power plant had no other source of income, its total income in 2013 was 528,040 EUR.

The greatest item in the list of expenses was the supply of the power plant with primary biomass. The biogas power plant grew sweet sorghum, vetch, medick, hay and energy grass on its own arable land, with its own agricultural machines; in addition, the organic and liquid manure also came from its own sources. Therefore, in case of these raw materials we calculated the cost price, which included the operational costs of the machines, the employees' wages, the costs of transportation and the also preparation of feedstock (Table 3). In the case of the self-produced materials, because of the short transport distances (see Table 2) the transportation costs were only 4,055 Euros, which is a mere $1.9 \%$ of the 218,242 EUR total cost of production.

In the case of the other raw materials which were purchased from external business partners, in addition to feedstock prices, significant transportation costs also emerged (Table 4). Moreover, in such cases, transportation costs were substantially higher than those associated with raw materials. This can be explained by the fact that the power plant purchased cheaper raw materials from relatively greater distances as well (see Table 2 ). 
Table 3: The costs of self-produced materials.

\begin{tabular}{|l|c|c|c|}
\hline \multicolumn{1}{|c|}{ Type of feedstock } & $\begin{array}{c}\text { Quantity } \\
\text { transported }\end{array}$ & $\begin{array}{c}\text { Unit price of raw } \\
\text { material (EUR/unit) }\end{array}$ & $\begin{array}{c}\text { Price of raw material } \\
\text { (EUR/unit) }\end{array}$ \\
\hline Sweet sorghum $(\mathrm{t})$ & 2,517 & 43.2 & 108,819 \\
\hline Vetch $(\mathrm{t})$ & 1,105 & 43.2 & 47,780 \\
\hline Medick $(\mathrm{t})$ & 1,025 & 43.2 & 44,316 \\
\hline Hay $(\mathrm{t})$ & 72 & 43.2 & 3,111 \\
\hline Energy grass $(\mathrm{t})$ & 68 & 43.2 & 2,944 \\
\hline Organic manure $(\mathrm{t})$ & 2,202 & 3.2 & 7,104 \\
\hline Liquid manure $\left(\mathrm{m}^{3}\right)$ & 12,920 & 0.3 & 4,168 \\
\hline Total: & & & $\mathbf{2 1 8 , 2 4 2}$ \\
\hline
\end{tabular}

Table 4: The cost of raw materials purchased from other business partners.

\begin{tabular}{|l|c|c|c|c|c|}
\hline Type of feedstock & $\begin{array}{c}\text { Quantity } \\
\text { transported (t) }\end{array}$ & $\begin{array}{c}\text { Unit price } \\
\text { of raw } \\
\text { material } \\
(\text { EUR/t) }\end{array}$ & $\begin{array}{c}\text { Price of raw } \\
\text { material } \\
(\text { EUR) }\end{array}$ & $\begin{array}{c}\text { Unit price of } \\
\text { transportation } \\
(\text { EUR/t) }\end{array}$ & $\begin{array}{c}\text { Price of } \\
\text { transportation } \\
\text { (EUR) }\end{array}$ \\
\hline Maize silage & 502 & 4.8 & 2,429 & 16.1 & 8,097 \\
\hline Maize silage & 1,687 & 3.2 & 5,442 & 16.1 & 27,210 \\
\hline Biodiesel waste & 2,381 & 16.1 & 38,410 & 16.1 & 38,410 \\
\hline Total: & & & $\mathbf{4 6 , 2 8 1}$ & & $\mathbf{7 3 , 7 1 6}$ \\
\hline
\end{tabular}

In total, the cost of supplying the power plant with feedstock - including both its own and purchased raw materials, and transportation - was 338,239 EUR in 2013.

In addition to obtaining the raw materials, ensuring the continuous operation of the power plant also has significant costs. In 2013, maintenance services required a total 51,050 EUR, and for replacement of certain component parts - based on the estimated lifetime of each element - a further 17339 EUR must be spent annually.

In 2013, the price of the purchased electric power that operated the power plant's serving units was 8,770 EUR. The total cost of the management's business trips in 2013 was 5,439 EUR; in addition, paying the 3 full-time employees meant a further expense of 32,742 EUR in the power plant's budget. The distribution (in percentages) of the operational costs of the power plant is shown in Figure 5.

Based on the results of the cost-benefit analysis, we established that in 2013 the direct operational cost of the power plant totaled 453,580 EUR, while it generated a 528,040 EUR income, which means a modest profit of 74,461 EUR. However, among the expenses we must also consider the 98,065 EUR payment by instalments for the bank loan, which means that the factory closed the year with a net minus of 23,604 EUR. Moreover, the power plant was only granted an operational permit for 20 years, and during this period it should generate the equivalent not only of the amount of the loans received (with interest), but its own investment of 668,326 EUR as well. Based on these results, we can establish that in the current working conditions, the power plant would be unable to keep operational in an economically sustainable way. Therefore, it is imperative to improve the cost/income ratio, which can be achieved by several realistic strategies. 


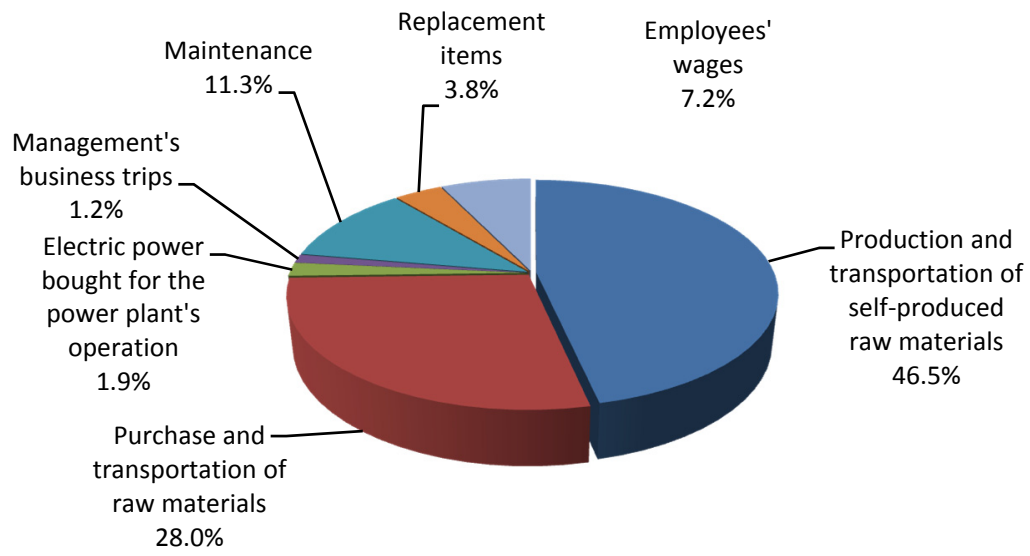

Figure 5: The distribution of operational costs in 2013.

The reduction of expenses can be primarily achieved via the rationalization of feedstock production, purchase and transportation. The most expensive item is the production of self-produced raw materials, which - despite the relatively small transportation costs - requires great sums of money. In May 2014 the power plant was granted permission to use tertiary bio-waste as a raw material, which could bring a serious improvement in its situation. According to estimates, in 2014 selfgrown vetch can be completely replaced by food industry waste, and in the following year sweet sorghum could also be replaced. What is more, the power plant may obtain this biowaste for free, and even its transportation will incur no additional costs, because for the partners that provide the waste it is still better and more advantageous to send their loads to the factory at their own expense than to have to render them harmless in any other way. This means the operational costs may decrease by as much as 150,000 Euros a year; so the factory may become profitable.

A further opportunity may be to cease the transportation of feedstock from the currently great distances and instead use locations that are closer to the power plant. There is a realistic chance of decreasing the ratio of raw materials (obtained from more than $90 \mathrm{~km}$ distances) from the present $35 \%$ to $20 \%$. If these raw materials could be supplied from within a $50 \mathrm{~km}$ radius, then this would mean (at least) a further 15,000 EUR saving per year; besides, the $\mathrm{CO}_{2}$ emissions would also be reduced by $7,600 \mathrm{~kg}$.

There are also opportunities to increase income. At the present moment the 1955 tons of solid biomanure produced is not utilized at all, while - during the agricultural production of self-produced feedstock - an annual 38.3 tons of artificial fertilizers are purchased and used, at a cost of 12,355 Euros. However, the biomanure produced could not only replace this amount of artificial fertilizers, but the remaining quantity - the equivalent of 110 tons of artificial fertilizers - could be used or sold, promising a further 35,483 EUR of income.

Another important possibility may be to use the currently wasted 2,659 MWh of thermal energy, which has a market value of 127,389 EUR. Although we see 
no real chance to achieve a continuous utilization over the whole year, this surplus thermal energy could be used in the cold seasons to heat greenhouses; in addition, the crop dryer (located at about $100 \mathrm{~m}$ from the power plant) may also be a potential target for heat recycling. According to careful estimates, the power plant may expect a further 50,000 EUR of income from the use of the currently wasted thermal energy.

\section{Conclusions}

In the present study, we examined the carbon footprint of a $0.637 \mathrm{MW}$ capacity power plant, and the economic sustainability of its operation. We established that in 2013 - regarding the complete life cycle of the power plant - the GHG emission was the equivalent of $208,173 \mathrm{~kg} \mathrm{CO}_{2}$. This is only $6.3 \%$ of the amount that would have been released had the same energy been produced within the scope of the current Hungarian energy structure. Therefore, biogas-based energy production is definitely an environmentally beneficial alternative.

However, the analysis of its economical sustainability resulted in a much less positive result. If the instalments of the bank loans are also taken into account, the power plant "produced" a 23,604 EUR deficit - and here we even ignored the company's own investment which also should be recovered in time. Therefore, it can be established that - under current conditions - the power plant cannot remain operational in an economically sustainable way. To achieve this, it is essential to improve the cost/income ratio. In this paper, we outlined several possible strategies to reach that goal. On the one hand, the amounts spent to purchase raw materials must be reduced radically, which can be achieved by starting to use biowaste from the food industry, and by reducing transportation distances. On the other hand, the incomes should also be increased, for example, by converting the produced biomanure and the (currently wasted) thermal energy into money.

\section{Acknowledgements}

The present work is supported by the TÁMOP-4.2.2.A-11/1/KONV-2012-0041 project. The project is co-financed by the European Union and the European Social Fund.

\section{References}

[1] World Bioenergy Association (WBA). WBA Global Bioenergy Statistics 2014, Stockholm, www.worldbioenergy.org/

[2] International Energy Agency (IEA). IEA Statistics, www.iea.org/statistics/

[3] European Biogas Association (EBA). Present status and future prospects of biogas/biomethane in Europe, http://european-biogas.eu/

[4] Sliz-Szkliniarz, B. \& Vogt, J., A GIS-based approach for evaluating the potential of biogas production from livestock manure and crops at a regional 
scale: A case study for the Kujawsko-Pomorskie Voivodeship. Renewable and Sustainable Energy Reviews, 16. pp. 752-763, 2012.

[5] Surendra, K.C., Takara, D., Hashimoto, A.G. \& Khanal S.K., Biogas as a sustainable energy source for developing countries: Opportunities and challenges. Renewable and Sustainable Energy Reviews, 31. pp. 846-859, 2014.

[6] Rico, C., Rico, J.R., Tejero, I., Muńoz, N. \& Gómez B., Anaerobic digestion of the liquid fraction of dairy manure in pilot plant for biogas production: Residual methane yield of digestate. Waste Management, 31. pp. 2167-2173, 2011.

[7] Adeoti, O., Ayelegun, T.A. \& Osho, S.O., Nigeria biogas potential from livestock manure and its estimated climate value. Renewable and Sustainable Energy Reviews, 37. pp. 243-248, 2014.

[8] Hamelin, L., Naroznova, I. \& Wenzel, H., Environmental consequences of different carbon alternatives for increased manure-based biogas. Applied Energy, 114. pp. 774-782, 2014.

[9] Thien, T.C.T., Cuong, P.H., Hang, L.T., Chao, N.V., Anh, L.X., Trach, N.X. \& Sommer, S.G., Manure management practices on biogas and non-biogas pig farms in developing countries - using livestock farms in Vietnam as an example. Journal of Cleaner Production, 27. pp. 64-71, 2012.

[10] Uusitalo, V., Havukainen, J., Manninen, K., Höhn, J., Lehtonen, E., Rasi, S., Soukka, R. \& Horttanainen M., Carbon footprint of selected biomass to biogas production chains and GHG reduction potential in transportation use, Renewable Energy, 66, pp. 90-98, 2014.

[11] Fazekas, I., Szabó, Gy., Szabó, Sz., Paládi, M., Szabó, G., Buday, T., Túri, Z. \& Kerényi A., Biogas utilization and its environmental benefits in Hungary, International Review of Applied Sciences and Engineering, 4(2). pp. 129-136, 2013.

[12] Carbon Trust. Conversion factors (Energy and carbon conversions, 2013 update), http://www.carbontrust.com/

[13] National Energy Strategy 2030, (in Hungarian) Ministry of National Development, 2012, Budapest.

[14] EEA (2012) Annual European Union greenhouse gas inventory 1990-2010 and inventory report 2012, http://www.eea.europa.eu/

[15] Grosz, B. P., Determining soil fluxes of GHGs $\left(\mathrm{CO}_{2}, \mathrm{~N}_{2} \mathrm{O}, \mathrm{CH}_{4}\right)$ in Hungarian agricultural and forest-clad areas (in Hungarian) $\mathrm{PhD}$ thesis, 2010, ELTE, Budapest.

[16] PAS 2050: 2011, Specification for the assessment of the life cycle greenhouse gas emissions of goods and services, BSI London. 